\title{
Integration of Earth Observation Data and Spatial Approach to Delineate and Manage Aeolian Sand-Affected Wasteland in Highly Productive Lands of Haryana, India
}

\author{
Kishan Singh Rawat $\mathbb{D}^{1},{ }^{1}$ Shashi Vind Mishra, ${ }^{2}$ and Sudhir Kumar Singh ${ }^{3}$ \\ ${ }^{1}$ Centre for Remote Sensing and Geoinformatics, Sathyabama Institute of Science and Technology, Chennai 600119, India \\ ${ }^{2}$ Division of Environmental Sciences, Indian Agricultural Research Institute, New Delhi 110012, India \\ ${ }^{3}$ K. Banerjee Centre of Atmospheric and Ocean Studies, IIDS, Nehru Science Centre, University of Allahabad, Allahabad, India \\ Correspondence should be addressed to Kishan Singh Rawat; ksr.kishan@gmail.com
}

Received 29 August 2017; Revised 30 January 2018; Accepted 20 February 2018; Published 27 March 2018

Academic Editor: Akhilesh Mishra

Copyright ( 2018 Kishan Singh Rawat et al. This is an open access article distributed under the Creative Commons Attribution License, which permits unrestricted use, distribution, and reproduction in any medium, provided the original work is properly cited.

\begin{abstract}
The western part of the country India is surrounded by Thar desert. Due to climate change, many regions in the world are facing different challenges. The objective of the study was to quantify the aeolian sand-affected land through integrated approach. The LANDSAT-ETM+ satellite image of 2009 has been used to distinguish recently affected areas by aeolian sand. A combined approach of digital classification backed with visual interpretation and ground verification was adopted. In addition to classification accuracy assessment was performed using field observations. Evidence based results of aeolian sand-affected areas have suggested that wasteland area has increased up to $4,427.55$ ha $(6.79 \%)$ of total geographical area. Two types of aeolian sands areas have been detected, namely, moderately affected (3,881.77 ha) and severely affected ( 545.79 ha). Moderately and severely affected aeolian soil lands have been more accurately mapped with reasonably good accuracy whereas smaller aeolian affected areas within croplands are mapped with low accuracy. The present study provides easy methodology for delineation, classification, and characterization of aeolian affected sands.
\end{abstract}

\section{Introduction}

Land resources are a valuable natural resource and it acts as a key for sustenance of mankind $[1,2]$. Overexploitation of land resources causes a significant change to the landforms, which has adverse effect to the environment [3]. The high population pressure, fast urbanization, rapid industrialization, and extensive agriculture have put great stresses on land resources, resulting into the substantial reduction in agricultural area and natural resources [4]. Tremendous population pressure is also leading to deforestation and resource degradation that has disturbed ecological balance of terrestrial ecosystems $[5,6]$. Hence, quantitative information about the nature, degree of extent, and spatiotemporal distribution of affected soils of India and the world is needed. It is essential for improved planning and need to implement strategic reclamation programs in proper time and cost-effective manner for huge crops production. In
India at national level wasteland mapping was conducted by conventional surveys and integrated (remote sensing and GIS) approaches from last four decades.

Management of land and water resources is essential to meet the economic growth of people in any country $[7,8]$. Land degradation is a serious problem; it can be controlled by afforestation practices on available wastelands in more scientific way $[9,10]$ and keep natural ecosystem in harmony and maintain ecological balance. Thus, the up-to-date and appropriate information about location and spatial extent of vacant/wastelands has played very important role for better planning of afforestation and treatment to eradicate the negative effects of land degradation [11, 12]. Hence, there is great demand to identify and reclaim these degraded lands in many countries [6] and in district of Sirsa of Haryana [13, 14].

Recent developments in geographical mapping allow the researchers to exercise the spatiotemporal distribution pattern and location aspects of land use/land cover (LULC) 
that can be studied more accurately using geospatial techniques (Saha 1990, [15-17]). Many studies have proven the applications of Remote Sensing and GIS in monitoring and management of natural resources $[6,18-20]$. Remote sensed data sets are used widely in studies, namely, groundwater [21], lake and wetlands $[22,23]$, land use/land cover mapping [24, $25]$, land use/land cover modeling [26, 27], crop suitability (Mustak et al. 2013), urban land use dynamics, forest mapping [28], soil characterization [29], slope estimation [30], landscape ecology [31], and watershed management [32]. Further, RS technology has proven its application in assessment of wasteland and its temporal monitoring [33, 34]. With the advent of satellite remote sensing mapping of degraded land has been started more efficiently at much finer scales [35]. The raw data which are affected by panoramic distortion, earth curvature, sensor detector failed, and detector line losses which are primarily corrected by data providers [36], hence, provide better mapping possibilities. Satellite remote sensing provides unbiased information about the objects. Satellite remote sensing has advantage over field based method in the forms of multispectral, synoptic coverage, very high temporal resolution, and cost effectiveness [37, 38]. Grunwald [4] has identified the spatial patterns and variations in landforms, land use, wasteland, and demographic characteristics and their spatial associations in satellite data. Genesis of wasteland and its typologies into degraded forests, undulating land, gullied and ravinous land, and degraded pastures, waterlogged, salt-affected, and sand-affected areas can be mapped and analyzed accurately with special reference to their relationship to natural environment [7]. Satellite data are of immense use for fine scale mapping of wastelands and may be helpful in implementing the schemes for wastelands development in given time $[9,39,40]$.

Saha et al. [41] integrated LANDSAT-TM dataset into GIS environment to map salt-affected and surface waterlogged/marshy lands with an accuracy of about $96 \%$ in parts of Aligarh district, Uttar Pradesh, India. Jain et al. [33] have identified the highly degraded scrub and sandy land on fringes of town and provided recommendations for future urban planning of the town where further development can be planned to avoid encroachment on good agricultural lands. Wasteland mappings of Karnal district (Haryana, India) using visual, monoscopic interpretations of MS LANDSAT-TM dataset of 1986 and ground truth were attempted [42, 43]. Pramila [18] used LANDSAT-TM dataset of 1988 and found that a major reason for formation of wasteland was severe wind erosion (Jalor and Ahor Tehsil of Jalor district of Western Rajasthan). The reflection of sand particles is being high; hence the sandy soil could be easily identified by false color composition (FCC) in LANDSATTM dataset. Sugumaran et al. [15] used IRS-1A, LISS-II data sets to delineate more accurately the wastelands at microlevel in Matar taluka of Kheda district (states of Gujarat, India) and generated area statistics of wastelands. Status of desertification was mapped with the application of satellite data in dry subhumid region of Panchkula district of Haryana by Arya et al. [44]. They found that nearly $47.5 \%$ of the total geographical area faces desertification (formation of wasteland states). Major outcomes from the study were that near about $32 \%$ of the total area of district's scrublands converted into desert mainly due to the unchecked desertification process. The change status of sodic lands has been prepared using satellite remote sensing data by Singh [16]. The desertification process is going on these regions; hence, we formulated our study with objectives as (i) identification and delineation of wastelands (at 1: 50,000 scale) using LANDSAT-ETM+ (2009) data set and (ii) creation of digital database in GIS environment.

\section{Materials and Methods}

2.1. Study Area. Sirsa district has an area of $4,276 \mathrm{~km}^{2}$ $\left(29.5400^{\circ} \mathrm{N}, 75.0300^{\circ} \mathrm{E}\right)$ with its headquarters being situated in Sirsa town (Figure 1). It is situated at nearly $255 \mathrm{~km}$ west of Delhi and $280 \mathrm{~km}$ from Southwest of Chandigarh. The Ghaggar River is flowing through central part of study area and Bhakra Canal is prime source of surface water for irrigation and drinking uses. The climate of region is tropical in nature with intensive hot summer and cool winter with a temperature variation of $47^{\circ} \mathrm{C}$ in June and $3^{\circ} \mathrm{C}$ in December and January. The average rainfall ranges between 200 and $300 \mathrm{~mm}$ and $80 \%$ precipitation is received during the four months (July to September; [45]). Consequently the agriculture in Sirsa district is threatened with nonavailability of water and the land related constraints too which is rendering a sizeable area into unproductive land due to aeolian spread of sands from the adjoining lands in the summers of each year. The terrain is broadly classified into moderately slopy to steep slope and highly undulating [46]. The terrain is divided into three major types, that is, Haryana plain, alluvial bed (Ghaggar or "nali"), and sand dune tract. The general slope varies from North to South.

2.2. Data Used and Analytical Procedures. In study the wastelands of Sirsa district, Haryana, have been delineated and mapped on 1:50,000 scale through digital image processing of LANDSAT-ETM+ image of 2009. Geocoded data was processed using image processing (ERDAS IMAGINE 8.7) software supported with the visual interpretation and ground truth. ArcGIS 9.3 was used for creation of digital database. LANDSAT-ETM+ digital data of 2 October 2009 was downloaded from web site (https://glovis.usgs.gov), and gap filling was applied using ENV4.8ver.

Collateral Data. For reference purposes, latest published reports, papers, and maps were used. For identification of village location, major transport networks, cultural features, and annotation of major towns and cities topo-sheets were obtained from different agencies and used. The groundwater report was used from Central Groundwater Board Report [46], agriculture information from [45], and information about the forestry from [45].

\section{Methodology}

Geometric correction was performed and later overlay was carried out using administrative boundary. False color composition (FCC) was generated using bands 2, 3, and 4 in blue, red, and green filters (Figure 2). Based on the standard 


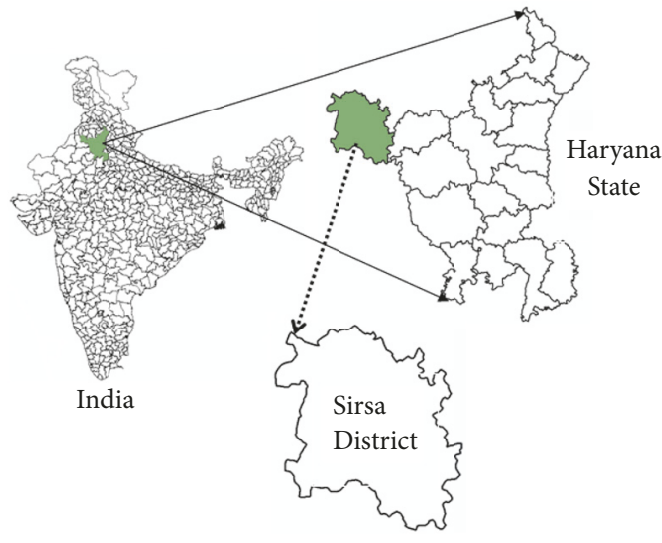

FIGURE 1: Location map of study area (Sirsa district of Haryana, India).

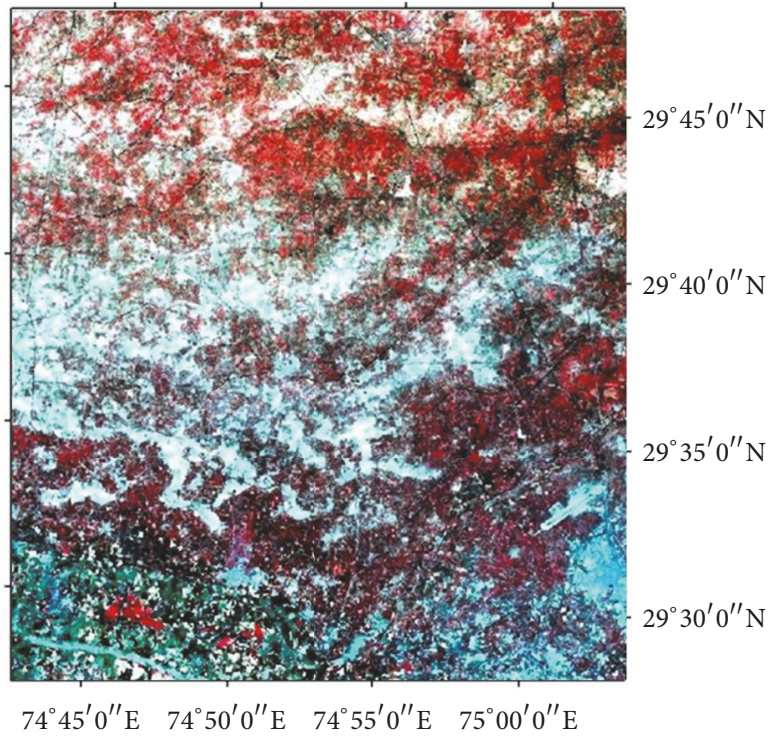

FIgURE 2: LANDSAT-ETM5+ false color composite map showing area affected by aeolian sand (in bright color, tones, and textures).

image interpretation key such as tone, texture, pattern, shape, size, location, and association, image was classified using Maximum Likelihood Classification (MLC) and visual interpretation. The readers can find the details of MLC in any standard remote sensing book (e.g., [48]). Following a standard legend prepared by Department of Space, Government of India (DOS, GOI) to delineate different wastelands categories was performed. A separate layer of settlement areas along with their names and major roads was also prepared. These maps were kept in GIS format further to create the database.

Training Signatures and Object Identification. By operating the classifier panel of the ERDAS IMAGINE 8.7, training signatures of the target (aeolian sand soil) were identified in two steps as (i) marking of training windows for various features by locating ground truth sites in the images and (ii) generation of signatures for training windows. Prior to training signature generation, identification of target is
TABLE 1: Accuracy assessment report.

\begin{tabular}{|c|c|c|c|c|}
\hline Class & $\begin{array}{l}\text { Severely } \\
\text { affected }\end{array}$ & $\begin{array}{c}\text { Moderately } \\
\text { affected }\end{array}$ & Settlement & $\begin{array}{l}\text { Row } \\
\text { total }\end{array}$ \\
\hline Severely affected & 70 & 5 & 0 & 75 \\
\hline Moderately affected & 3 & 55 & 0 & 58 \\
\hline Settlement & 0 & 0 & 121 & 121 \\
\hline Column total & 73 & 60 & 121 & 254 \\
\hline \multicolumn{5}{|c|}{ Error matrix } \\
\hline $\begin{array}{l}\text { Agreement/accuracy } \\
\text { (in \%) }\end{array}$ & 95.89 & 91.67 & 100 & \\
\hline Omission error (in \%) & 4.11 & 8.33 & 100 & \\
\hline Commission error (in \%) & 6.67 & & & \\
\hline Overall accuracy (in \%) & 96.85 & & & \\
\hline
\end{tabular}

important. It was found that different objects had unique spectral signatures. Differences in photographic tone or texture or both are the basis for target identification coupled with knowledge of the target. They depend on the reflectance power of leaves and also on the soil cover ratio, which in turn depends on the stage of nutrient status and moisture status of the soil. Photographic texture depends on nature of soil and spacing between soil particles and scale of the photograph. The spectral signature of soil is influenced by the underlying soil and residue. The signature is subsequently modified by the appearance and gradual increase in surface coverage of particular soil. Knowing the manner in which soil characteristics is recorded photographically and the ability to associate these with the knowledge of soil identification was done successfully. The exact locations of ground truth sites were recorded with the help of Global Positioning System (GPS). Before freezing the training signatures, trial classification was run on respective sampled images. As per the requirement some training sites which were not suitable were hence discarded while some were modified to proceed with classification process. MLC method was used to classify LANDSAT-ETM+ (Path/Row 148/40) imagery using ground truth data which widely used parametric classifier for satellite data analysis and it relies on the second-order statistics of Gaussian probability density functions (PDFs) used to classify unidentified pixel belonging to each category.

\section{Results and Discussions}

The accuracy assessment in Table 1 shows that the overall accuracy of classified image is 96.85 . The delineated wasteland areas are illustrated (Figure 3). The district is comprised of 4.27 lac hectares (ha), which is $9.66 \%$ of area of Haryana state. The area taken under study was $65,176.93$ ha which constitutes nearly $15.24 \%$ of the total geographical area of the district. It was found that the wastelands in the study area covered approximately $4,427.55$ ha which constitutes nearly $6.79 \%$ of the total geographical extents. The main wasteland category is aeolian sand. This analysis has completely upgraded the land use statistics of district which can be used for effective planning of its proper development and management of resources in a more sustainable manner. 


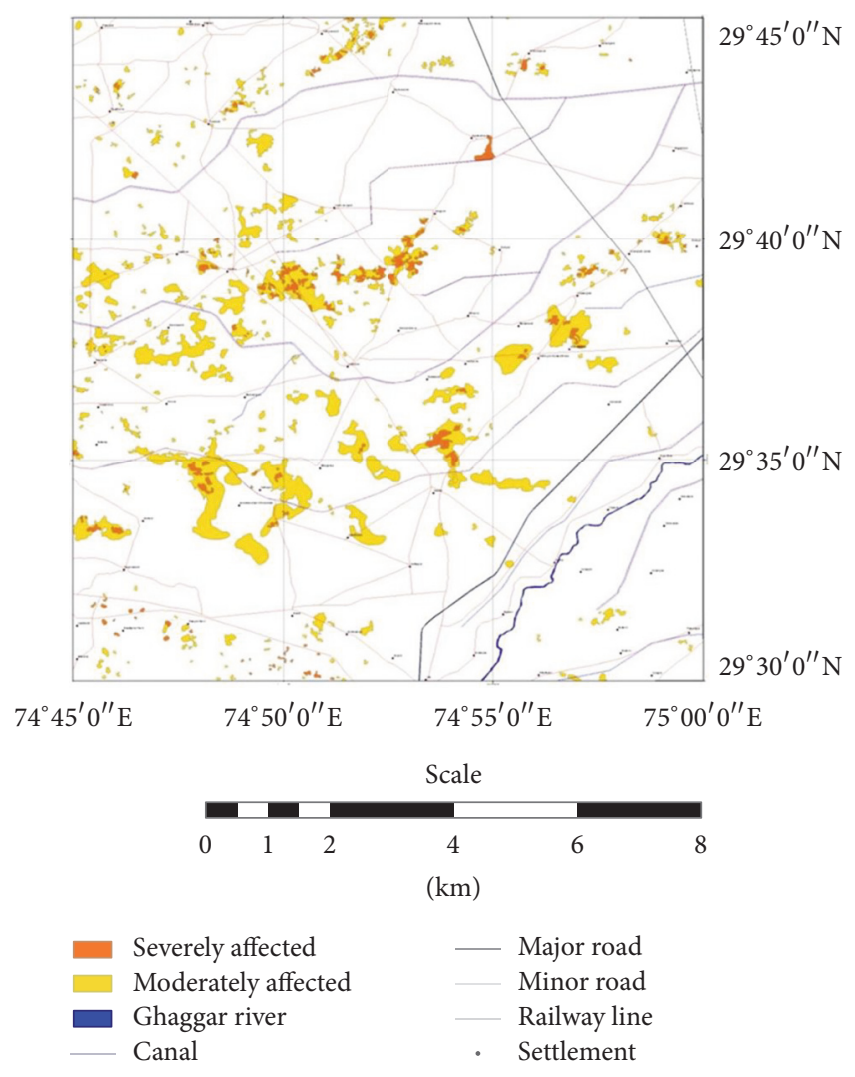

FIGURE 3: Map showing area affected by aeolian sand in Sirsa District of Haryana, India.

4.1. Aeolian Sand. The majority of land areas is sandy and is characterized by accumulation of sand in the form of varying size of sand dunes having variable shapes and sizes that have developed as a result of transportation of soil through wind processes. The main cause of aeolian sand is due to adjacency to the Rajasthan State that lies under arid climatic condition and resulted into soil erosion due to wind. The directional flow of sand is more in the Sirsa region. The area encompasses sandy soils with low to very low soil moisture and low organic matter. The productivity of such types of soil is low. Hence soil loss in the form of deposits of sand dune and sand transportation is very frequent by wind erosion. Wind erosion generally forms two types of wasteland, which are discussed below.

4.1.1. Lands Moderately Affected by Aeolian Process. Areas that come under this category were found to be approximately $3,881.77$ ha (5.96\%) of study area. The majority of land is moderately affected by aeolian sands and has good amount of organic matter content and higher soil moisture retention compared to severely affected lands. The slightly better soils have good agricultural activities in this region and have better productive yield. However, it still needs to be managed through appropriate agricultural practices in proper manner. In condition of extreme utilization without proper conservation and management practices, it enhances severe soil loss condition and complete degradation. Moderately affected soils may convert into fertile soil by adopting proper agricultural practices and thus can be optimized for better agriculture utilities.

4.1.2. Lands Severely Affected by Aeolian Process. The severely affected soils have covered approximately 545.79 ha $(0.84 \%)$; hence urgent need is required to take proper care and management. The moderately affected land is also getting converted into severely affected land because of deforestation and nonscientific agriculture practices. It is very difficult to ameliorate severely affected soils because of their bad physical and biological conditions, although they can be used for horticultural plantations, agri-silvi or agri-silvi-pastoral purposes, and for conservation agriculture to some extent with much effort on soil conservation measures.

4.2. The Piedmont Plains of Ghaggar River. The Ghaggar, an important rain fed river of length $85 \mathrm{~km}$ in district, has major drainage channel. The area occupied by the piedmont plains of Ghaggar River is approximately $0.14 \%$. The river flooded in South West monsoon and causes extensive damage to crops and property. Soils around the river region are sandy to loamy sand at places underlined by lime concretion and gypsiferous substrata. Some places are also covered with sand hummocks and sand dunes. The soil is low in nitrogen, organic carbon, and phosphorus contents.

Most of the area is covered by aeolian sand; it has fine particles and is continuously varying. Because wastelands are an important aspect in land use planning and developmental activities of any area, so all the database on wastelands was created and put in GIS.

\section{Recommendations and Reclamation Measures, Management, and Adaptation}

Wind erosion is a major problem. The top soil erosion leads to loss of organic matter, damage to crops, and burial of productive agricultural lands. Farmers are protecting and managing their agricultural fields especially through crop residue and fencing during critical periods. Two major control activities are recommended as aeolian sand stabilization and shelter belt plantation (Table 2) and some improved methods are also given below for aeolian sand stabilization being followed in similar conditions elsewhere in the world [8, 49-53].

Gap Filling/Regeneration of Tree Species on Degraded Forest Land. Afforestation can be used in gap filling with transplanting. Suitable plant species like Acacia nilotica, Acacia tortilis, Dalbergia sissoo, Azadirachta indica, Eucalyptus camaldulensis, Popular, Tamarix species, and so forth can be used for the transplanting. The ground flora should be enriched by growing suitable shrub and grass species in contour furrows. However, uncontrolled grazing should be restricted and properly regulated for forest regeneration.

Brushes and Mulches. Brushes or mulches act as surface covers and wind barriers against erosion from the wind. They prevent loss of top soil, retain moisture and provide shelter for developing seedlings, and enhance sand accretion. Accreting 
TABLE 2: Plant species suitable for aeolian sand stabilization.

\begin{tabular}{|c|c|c|c|}
\hline Annual rainfall zone (mm) & Trees & Shrubs & Grasses \\
\hline $150-300$ & $\begin{array}{c}\text { Prosopis juliflora, Acacia tortilis, } \\
\text { A. senegal }\end{array}$ & $\begin{array}{c}\text { Calligonum polygonoides, } \\
\text { Ziziphus nummularia, Citrullus } \\
\text { colocynthis, Ziziphus mauritiana }\end{array}$ & Lasiurus sindicus \\
\hline $300-400$ & $\begin{array}{l}\text { A. tortilis, A. senegal, P. juliflora, } \\
\text { P. cineraria, Tecomella undulata, } \\
\text { Parkinsonia aculeata, Acacia } \\
\text { nubica, Dichrostachys glomerata, } \\
\text { Colophospermum mopane, } \\
\text { Cordia rothii }\end{array}$ & $\begin{array}{l}\text { Z. nummularia, C. polygonoides, } \\
\text { Citrullus colocynthis }\end{array}$ & $\begin{array}{c}\text { C. setigerus, L. sindicus, } \\
\text { Saccharum munja, C. ciliaris }\end{array}$ \\
\hline $400-550$ & $\begin{array}{l}\text { A. tortilis, P. cineraria, P. juliflora, } \\
\text { A. senegal, Dalbergia sissoo, } \\
\text { Ailanthus excelsa, Albizia lebbeck, } \\
\text { P. aculeata, T. undulata, D. } \\
\text { glomerata, C. mopane }\end{array}$ & Z. mauritiana, Cassia auriculata & $\begin{array}{l}\text { Cenchrus ciliaris, C. setigerus, } \\
\text { S. munja, Panicum antidotale }\end{array}$ \\
\hline
\end{tabular}

Source. Adopted from [47].

sand stimulates the growth of primary colonizing grasses such as Spinifex.

Liquid Sprays. Liquid sprays such as emulsified bitumen or dispersed organic polymers provide temporary stabilization by aggregating or cementing sand grains so that they cannot be moved by the wind. Unlike brushes and mulches, these products do not enhance sand accretion; mobile sand simply passes over the surface and continues until intercepted by other obstacles. Recommended sprays do not interfere with the germination or with the growth of seedlings, transplanted culms, or runners. Most allow reasonable air and water exchange between the atmosphere and stabilized sand [54].

Cover Crops. Cover crops are generally intolerant of strong winds and significant sand burial. Thus, where there is no migrating sand to accrete and it is a matter of holding the sand surface in place while secondary or tertiary species are established, then a living plant mulch or cover crop is appropriate. By necessity, cover crops must germinate rapidly and grow vigorously to provide a dense vegetative cover capable of reducing the wind velocity at the sand surface. Cover crops may be used to provide sand surface stability and to protect emerging secondary species or they may be used in their own right as a longer term surface stabilizer. The length of time they persist can be controlled by species selection and by management of fertilizer inputs.

\section{Conclusions}

In this work, wasteland mapping has been carried out of year 2009. The satellite image was classified using MLC based supervised classification, and total 65,176.93 ha of land area is classified as wasteland, in which $3,881.77$ ha area was mapped as moderately and 545.79 ha as severely affected by aeolian sand. The more accurate mapping of aeolian soil encrusted lands with large contiguous areas whereas slightly affected land having less affected areas within croplands was mapped less accurately. The previous and current national scenarios of aeolian affected soils using traditional and RS approaches can be refined and all other national estimates of wasteland (especially aeolian sand-affected soil) mapping can be subjected to the present methodology and approach can be subjected to the reconciliation. It can be stated that fine resolution satellite data sets facilitate interpretation to further differentiate a wasteland class delineated on moderate spatial resolution satellite data. Moreover, these data are found to be useful in achieving high mapping accuracy in delineation of wasteland classes.

\section{Conflicts of Interest}

The authors declare that there are no conflicts of interest regarding the publication of this paper.

\section{Acknowledgments}

The authors are grateful to the authorities of their respective organization for having allowed them to undertake parts of the whole analysis/ground truth/collection of secondary information and so forth. Thanks are due to the Chairman and members of the advisory of the fourth author. All help and information received from known and unknown sources are also duly acknowledged.

\section{References}

[1] National Commission on Agriculture, Report of the National Commission on Agriculture, Ministry of Agriculture and Irrigation, Government of India, New Delhi, India, 1976.

[2] T. V. Ramachandra, "Comparative assessment of techniques for bio-resource monitoring using GIS and remote sensing," The ICFAI; Journal of Environmental Sciences, vol. 1, no. 2, pp. 2-8, 2007.

[3] V. K. Verma, Assessment of land degradation by integrated anal$y$ sis of spectrally based information and terrain attributes in semiarid region [M.Sc. thesis], IIRS and ITC, Dehradun, India, 2005.

[4] S. Grunwald, "The current state of digital soil mapping and what is next," in Digital Soil Mapping: Bridging Research, Production and Environmental Applications, J. L. Boetinger, D. W. Howell, 
A. C. Moore, A. E. Hartemink, and S. Kienst-Brown, Eds., pp. 3-12, Springer, Heidelberg, Germany, 2013.

[5] A. Sharma, T. Moorti, and S. K. Chauhan, "A study on the estimation of wasteland and proposed strategy for their regeneration in Western Himalayas; agricultural situation in India 47 CSSRI-2007," Annual Report 2006-07, 1992.

[6] T. Chandramohan and D. G. Durbude, "Estimation of soil erosion potential using universal soil loss equation," Journal of the Indian Society of Remote Sensing, vol. 30, no. 4, pp. 181-190, 2002.

[7] G. Francis, R. Edinger, and K. Becker, "A concept for simultaneous wasteland reclamation, fuel production, and socioeconomic development in degraded areas in India: Need, potential and perspectives of Jatropha plantations," Natural Resources Forum, vol. 29, no. 1, pp. 12-24, 2005.

[8] S. Diniega, C. J. Hansen, J. N. McElwaine et al., "A new dry hypothesis for the formation of martian linear gullies," Icarus, vol. 225, no. 1, pp. 526-537, 2013.

[9] R. S. Dwivedi, T. Ravi Sankar, L. Venkataratnam et al., "The inventory and monitoring of eroded lands using remote sensing data," International Journal of Remote Sensing, vol. 18, no. 1, pp. 107-119, 1997.

[10] Haryana Space Applications Centre, Wastelands Atlas of Haryana, Haryana State Remote Sensing Application Centre (HARSAC), Department of Science and Technology, Government of Haryana, 2006.

[11] J. F. L. Contador, S. Schnabel, A. Gómez Gutiérrez, and M. P. Fernández, "Mapping sensitivity to land degradation in Extremadura, SW Spain," Boletín de la Asociación de Geógrafos Españoles, vol. 53, pp. 387-390, 2008.

[12] S. Nawar, H. Buddenbaum, and J. Hill, "Digital mapping of soil properties using multivariate statistical analysis and ASTER data in an Arid region," Remote Sensing, vol. 7, no. 2, pp. 11811205, 2015.

[13] V. P. Goyal, R. L. Ahuja, B. S. Sangwan, and M. L. Manchanda, "Application of remote sensing technique in wasteland mapping and their landuse planning in Karnal District of Haryana State (India)," in Proceedings of the 13th Annual International Geoscience and Remote Sensing Symposium, vol. 2, pp. 932-934, Tokyo, Japan, August 1993.

[14] Agriculture Situations in District Sirsa, Haryana, India, 2014, https://sirsa.gov.in/.

[15] R. Sugumaran, G. Sandhya, K. S. Rao, R. N. Jadhav, and M. M. Kimothi, "Potential of satellite data in delineation of wastelands and correlation with ground information," Journal of the Indian Society of Remote Sensing, vol. 22, no. 2, pp. 113-118, 1994.

[16] A. N. Singh, "Geospatial database for sustainable reclamation of degraded lands," in Proceedings of the Abstracts of the ISPRS TC-IV International Symposium on Geo Spatial Databases for Sustainable Development, pp. 151-152, Goa, India, 2006.

[17] D. P. Rao, "emote sensing application for land use and urban planning: retrospective and perspective," in Proceedings of the ISRS National Symposium on Remote Sensing Application for Natural Resources Retrospective and Perspective, pp. 287-297, Bangalore, India, January 1999.

[18] R. Pramila, "Assessment of soil degradation Hazards in Jalor and Ahor Tehsil of Jalor district (Western Rajasthan) by remote sensing," Journal of the Indian Society of Remote Sensing, vol. 22, no. 3, pp. 169-181, 1994.

[19] G. Metternicht I and J. Zinck A, Remote Sensing of Soil Salinization: Impact on Land Management, CRC Press, Taylor \& Francis Group, Boca Raton, Fla, USA, 2008.
[20] V. L. Mulder, S. de Bruin, and M. E. Schaepman, "Representing major soil variability at regional scale by constrained Latin Hypercube Sampling of remote sensing data," International Journal of Applied Earth Observation and Geoinformation, vol. 21, no. 1, pp. 301-310, 2013.

[21] S. K. Singh, C. K. Singh, and S. Mukherjee, "Impact of landuse and land-cover change on groundwater quality in the Lower Shiwalik hills: A remote sensing and GIS based approach," Central European Journal of Geosciences, vol. 2, no. 2, pp. 124131, 2010.

[22] J. K. Thakur, P. K. Srivastava, A. K. Pratihast, and S. K. Singh, "Estimation of evapotranspiration from wetlands using geospatial and hydrometeorological data," in Geospatial Techniques for Managing Natural Resources, J. K. Thakur, S. K. Singh, A. Ramanathan, M. B. K. Prasad, and W. Gossel, Eds., pp. 53-67, Springer and Capital, 2012.

[23] J. K. Thakur, P. K. Srivastava, and S. K. Singh, "Ecological monitoring of wetlands in semi-arid Konya closed basin, Turkey," Regional Environmental Change, vol. 12, no. 1, pp. 133-144, 2012.

[24] S. K. Singh, A. C. Pandey, and D. Singh, "Land use fragmentation analysis using remote sensing and Fragstats," in Remote Sensing Applications in Environmental Research, P. K. Srivastava, S. Mukherjee, T. Islam, and M. Gupta, Eds., chapter 9, pp. 151-176, Springer International Publishing, Cham, Switzerland, 2014.

[25] S. K. Singh, P. K. Srivastava, M. Gupta, J. K. Thakur, and S. Mukherjee, "Appraisal of land use/land cover of mangrove forest ecosystem using support vector machine," Environmental Earth Sciences, vol. 71, no. 5, pp. 2245-2255, 2014.

[26] S. K. Singh, S. Mustak, P. K. Srivastava, S. Szabó, and T. Islam, "Predicting spatial and decadal LULC changes through cellular automata markov chain models using earth observation datasets and geo-information," Environmental Processes, vol. 2, no. 1, pp. 61-78, 2015.

[27] S. Mustak, N. K. Baghmar, and S. K. Singh, "Prediction of industrial land use using linear regression and MOLA techniques: a case study of Siltara industrial belt," Landscape \& Environment, vol. 9, no. 2, pp. 59-70, 2015.

[28] S. K. Singh, S. K. Kewat, B. Aier, V. P. Kanduri, and S. Ahirwar, "Plant community characteristics and soil status in different land use systems at Dimapur, Nagaland, India," Forest Research Papers, vol. 73, no. 4, pp. 305-312, 2012.

[29] D. Paudel, J. K. Thakur, S. K. Singh, and P. K. Srivastava, "Soil characterization based on land cover heterogeneity over a tropical landscape: an integrated approach using earth observation data-sets," Geocarto International, vol. 30, no. 2, pp. 218-241, 2015.

[30] G. Szabó, S. K. Singh, and S. Szabó, "Slope angle and aspect as influencing factors on the accuracy of the SRTM and the ASTER GDEM databases," Physics and Chemistry of the Earth, vol. 8384, pp. 137-145, 2015.

[31] S. K. Singh, P. K. Srivastava, S. Szabó, G. P. Petropoulos, M. Gupta, and T. Islam, "Landscape transform and spatial metrics for mapping spatiotemporal land cover dynamics using Earth Observation data-sets," Geocarto International, vol. 32, no. 2, pp. 113-127, 2017.

[32] S. K. Yadav, S. K. Singh, M. Gupta, and P. K. Srivastava, "Morphometric analysis of Upper Tons basin from Northern Foreland of Peninsular India using CARTOSAT satellite and GIS," Geocarto International, vol. 29, no. 8, pp. 895-914, 2014.

[33] A. K. Jain, R. S. Hooda, J. Nath, and M. L. Manchanda, "Mapping and monitoring of urban landuse of Hisar Town, Haryana using 
remote sensing techniques," Journal of the Indian Society of Remote Sensing, vol. 19, no. 2, pp. 125-134, 1991.

[34] T. E. Barchyn, R. L. Martin, J. F. Kok, and C. H. Hugenholtz, "Fundamental mismatches between measurements and models in aeolian sediment transport prediction: The role of small-scale variability," Aeolian Research, vol. 15, pp. 245-251, 2014.

[35] F. M. Breunig, L. S. Galvão, and A. R. Formaggio, "Detection of sandy soil surfaces using ASTER-derived reflectance, emissivity and elevation data: Potential for the identification of land degradation," International Journal of Remote Sensing, vol. 29, no. 6, pp. 1833-1840, 2008.

[36] S. Mustak, N. K. Baghmar, and S. K. Singh, "Correction of atmospheric haze of IRS-1C LISS-III multispectral satellite imagery: an empirical and semi-empirical based approach," Landscape \& Environment, vol. 10, no. 2, pp. 63-74, 2016.

[37] L. Xiaoyan, Z. Wang, S. Kaishan, Z. Bai, L. Dianwei, and G. Zhixing, "Assessment for salinized wasteland expansion and land use change using GIS and remote sensing in the west part of Northeast China," Environmental Modeling \& Assessment, vol. 131, no. 1-3, pp. 421-437, 2007.

[38] K. Whitehead, C. H. Hugenholtz, S. Myshak et al., "Remote sensing of the environment with small unmanned aircraft systems (UASs), part 2: scientific and commercial applications," Journal of Unmanned Vehicle Systems, vol. 2, no. 3, pp. 86-102, 2014.

[39] S. Grunwald, J. A. Thompson, and J. L. Boettinger, "Digital soil mapping and modeling at continental scales: Finding solutions for global issues," Soil Science Society of America Journal, vol. 75, no. 4, pp. 1201-1213, 2011.

[40] I. Delgado-Fernandez, R. Davidson-Arnott, B. O. Bauer, I. J. Walker, J. Ollerhead, and H. Rhew, "Assessing aeolian beachsurface dynamics using a remote sensing approach," Earth Surface Processes and Landforms, vol. 37, no. 15, pp. 1651-1660, 2012.

[41] S. K. Saha, M. Kudrat, and S. K. Bhan, "Digital processing of Landsat TM data for wasteland mapping in parts of Aligarh District (Uttar Pradesh), India," International Journal of Remote Sensing, vol. 11, no. 3, pp. 485-492, 1990.

[42] K. Anderson and H. Croft, "Remote sensing of soil surface properties," Progress in Physical Geography, vol. 33, no. 4, pp. 457-473, 2009.

[43] V. L. Mulder, S. de Bruin, M. E. Schaepman, and T. R. Mayr, “The use of remote sensing in soil and terrain mapping-a review," Geoderma, vol. 162, no. 1-2, pp. 1-19, 2011.

[44] V. S. Arya, H. Singh, R. S. Hooda, and A. S. Arya, "Desertification change analysis in siwalik hills of Haryana using geoinformatics," in International Archives of the Photogrammetry, Remote Sensing and Spatial Information Sciences, vol. XL-8 of 2014 ISPRS Technical Commission VIII Symposium, December 2014, Hyderabad, India, 2014.

[45] https://sirsa.gov.in/.

[46] http://cgwb.gov.in/District_Profile/Haryana/Sirsa.pdf.

[47] P. C. Moharana, P. Santra, D. V. Singh et al., "ICAR-Central Arid Zone Research Institute, Jodhpur: Erosion processes and desertification in the Thar Desert of India," Proceedings of the Indian Academy of Science, vol. 82, no. 3, pp. 1117-1140, 2016.

[48] T. M. Lillesand and R. W. Kiefer, Remote Sensing and Image Interpretation, John Wiley, New York, NY, USA, 5th edition, 2004.

[49] A. S. Hickin, B. Kerr, T. E. Barchyn, and R. C. Paulen, "Using ground-penetrating radar and capac $\pi$ tvely coupled resistivity to investigate 3-D fluvial architecture and grain-size distribution of a gravel floodplain in northeast British Columbia, Canada," Journal of Sedimentary Research, vol. 79, no. 6, pp. 457-477, 2009.

[50] C. H. Hugenholtz and T. E. Barchyn, "Spatial analysis of sand dunes with a new global topographic dataset: New approaches and opportunities," Earth Surface Processes and Landforms, vol. 35, no. 8, pp. 986-992, 2010.

[51] C. H. Hugenholtz, N. Levin, T. E. Barchyn, and M. C. Baddock, "Remote sensing and spatial analysis of aeolian sand dunes: A review and outlook," Earth-Science Reviews, vol. 111, no. 3-4, pp. 319-334, 2012.

[52] C. H. Hugenholtz, O. W. Brown, and T. E. Barchyn, "Estimating aerodynamic roughness $\left(z_{0}\right)$ from terrestrial laser scanning point cloud data over un-vegetated surfaces," Aeolian Research, vol. 10, pp. 161-169, 2013.

[53] C. H. Hugenholtz, K. Whitehead, O. W. Brown et al., "Geomorphological mapping with a small unmanned aircraft system (sUAS): Feature detection and accuracy assessment of a photogrammetrically-derived digital terrain model," Geomorphology, vol. 194, pp. 16-24, 2013.

[54] A. S. Hickin, B. Kerr, D. G. Turner, and T. E. Barchyn, "Mapping Quaternary paleovalleys and drift thickness using petrophysical logs, northeast British Columbia, Fontas map sheet, NTS 94I," Canadian Journal of Earth Sciences, vol. 45, no. 5, pp. 577-591, 2008. 

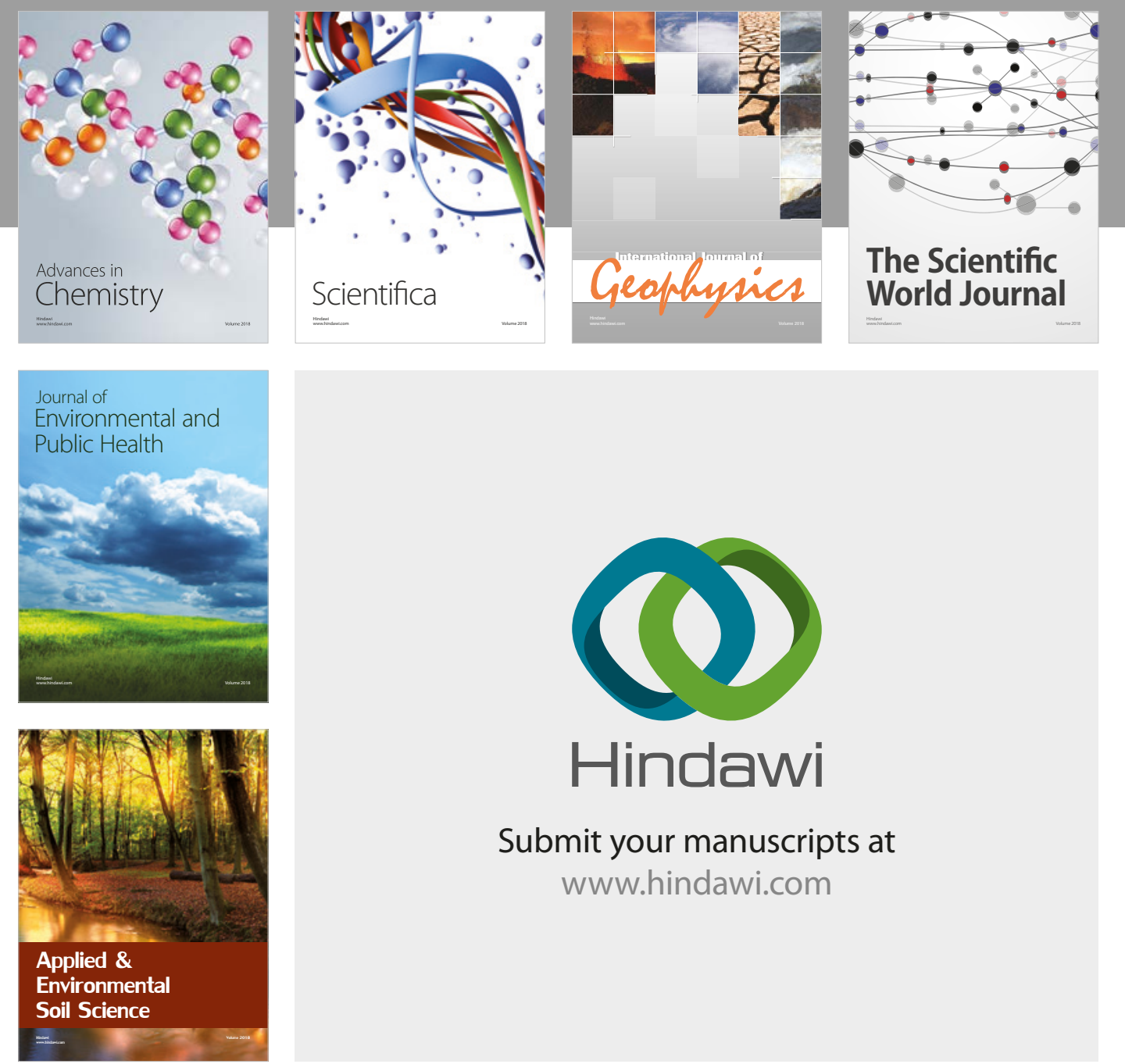

The Scientific

\section{World Journal}
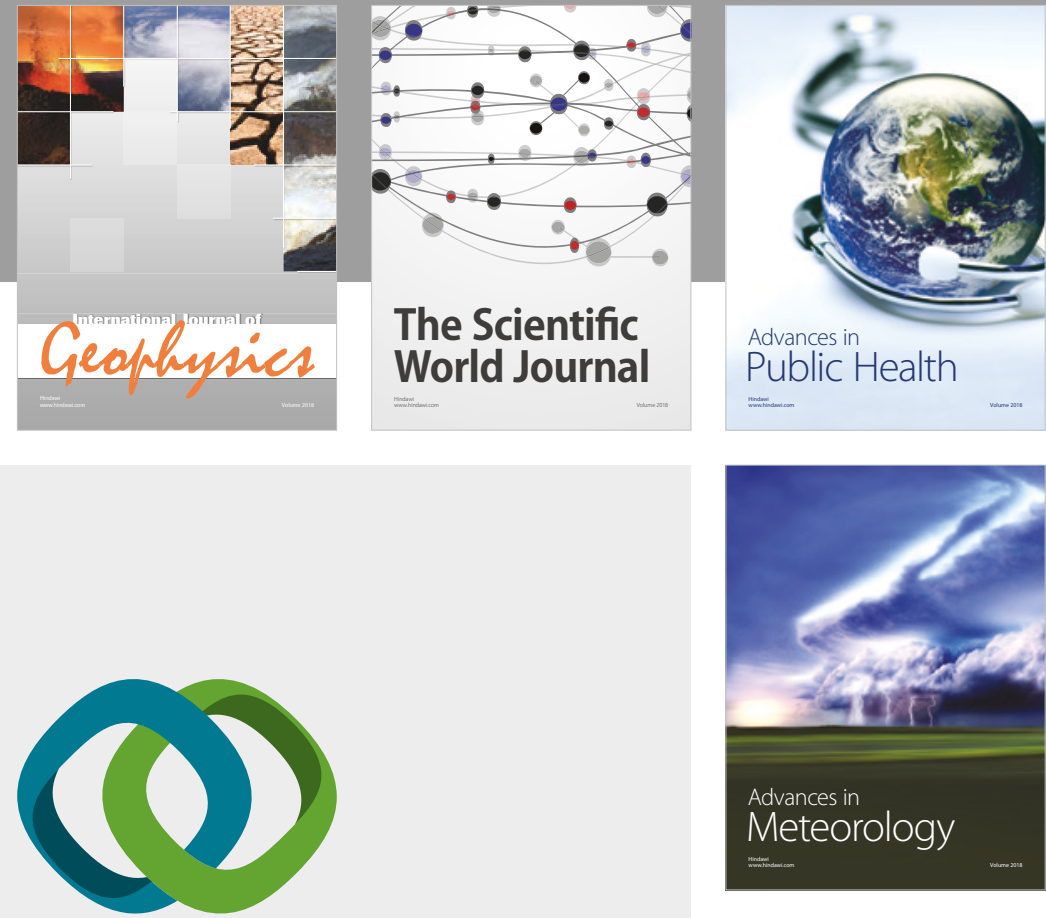

Advan

Public Health

\section{Hindawi}

Submit your manuscripts at

www.hindawi.com
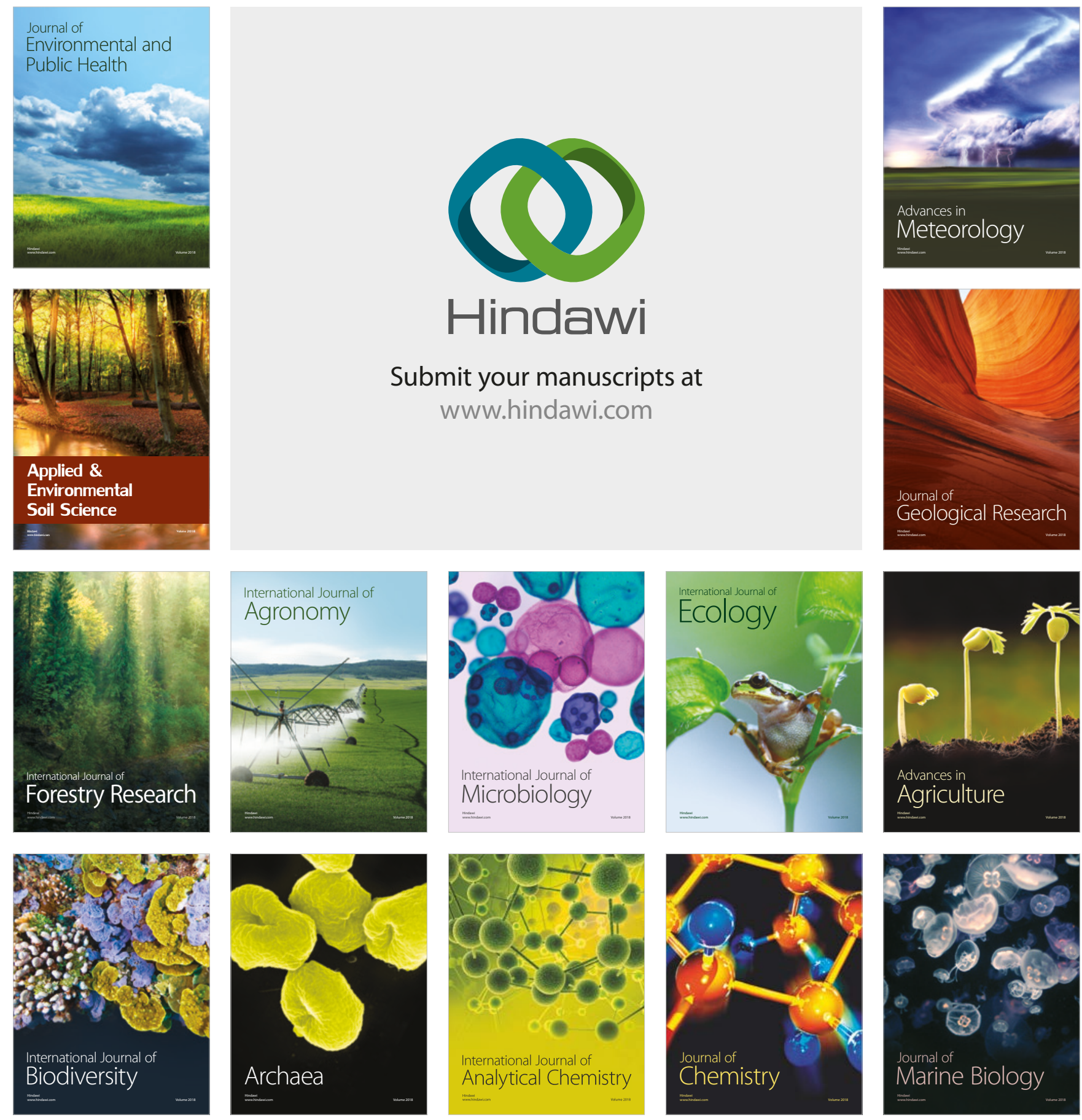